\title{
Genetic parameters for growth, reproductive and maternal traits in a multibreed meat sheep population
}

\author{
Ana Maria Bezerra Oliveira Lôbo ${ }^{1}$, Raimundo Nonato Braga Lôbo ${ }^{1,2}$, Samuel Rezende Paiva ${ }^{3}$, \\ Sônia Maria Pinheiro de Oliveira ${ }^{1}$ and Olivardo Facó $^{2}$ \\ ${ }^{1}$ Departamento de Zootecnia, Universidade Federal do Ceará, Fortaleza, CE, Brazil. \\ ${ }^{2}$ Embrapa Caprinos e Ovinos, Sobral, CE, Brazil. \\ ${ }^{3}$ Embrapa Recursos Genéticos e Biotecnologia, Brasília, DF, Brazil.
}

\begin{abstract}
The genetic parameters for growth, reproductive and maternal traits in a multibreed meat sheep population were estimated by applying the Average Information Restricted Maximum Likelihood method to an animal model. Data from a flock supported by the Programa de Melhoramento Genético de Caprinos e Ovinos de Corte (GENECOC) were used. The traits studied included birth weight (BW), weaning weight (WW), slaughter weight (SW), yearling weight $(\mathrm{YW})$, weight gain from birth to weaning (GBW), weight gain from weaning to slaughter (GWS), weight gain from weaning to yearling (GWY), age at first lambing (AFL), lambing interval (LI), gestation length (GL), lambing date (LD number of days between the start of breeding season and lambing), litter weight at birth (LWB) and litter weight at weaning (LWW). The direct heritabilities were $0.35,0.81,0.65,0.49,0.20,0.15$ and 0.39 for BW, WW, SW, YW, GBW, GWS and GWY, respectively, and $0.04,0.06,0.10,0.05,0.15$ and 0.11 for AFL, LI, GL, LD, LWB and LWW, respectively. Positive genetic correlations were observed among body weights. In contrast, there was a negative genetic correlation between GBW and GWS (-0.49) and GBW and GWY (-0.56). Positive genetic correlations were observed between AFL and LI, LI and GL, and LWB and LWW. These results indicate a strong maternal influence in this herd and the presence of sufficient genetic variation to allow mass selection for growth traits. Additive effects were of little importance for reproductive traits, and other strategies are necessary to improve the performance of these animals.
\end{abstract}

Key words: age at first lambing, genetic correlation, heritability, body weight, litter weight.

Received: December 19, 2008; Accepted: June 9, 2009.

\section{Introduction}

The Brazilian meat sheep industry has expanded in recent years mainly through an increase in the number of farmers. However, performance indexes are lower than those required to guarantee efficiency and competitiveness compared with other animal sectors. Dickerson (1970) suggested that increasing the number of lambs marketed per ewe per year is an important measure to improve the efficiency of meat sheep production. However, in Brazil, local breeds show low productivity, which leads breeders to cross these with exotic breeds. Crossbreeding programs have been so widely used in the tropics that very few within-breed selection experiments have been done (Kosgey et al., 2004). Because selection to enhance reproductive traits in sheep is rather slow, the crossbreeding of local breeds with highly prolific breeds is widespread in several countries, the aim being to increase lamb production by ex-

Send correspondence to Raimundo Nonato Braga Lobo. Embrapa Caprinos, Estrada Sobral Groaíras km 4, Caixa Postal 145, 62011970 Sobral, CE, Brazil. E-mail: lobo@ cnpc.embrapa.br. ploiting the additive and non-additive effects of genes (El Fadili and Leroy, 2001). The study of these aspects in Brazilian multibreed populations is necessary since most investigations have concentrated on performance analysis (Silva and Araújo, 2000; Silva, 2002; Barros et al., 2004, 2005). Consequently, the genetic variation in these populations is unknown.

Hall et al. (1995) reported direct and maternal heritabilities for birth weight of 0.03 and 0.24 , respectively, in crossbred animals, whereas Pitono and James (1995) stated that for a tropical breed the corresponding values for these heritabilities were 0.13 and 0.08 , respectively. Genetic parameters for weaning weight, carcass traits and ovulation rates have been reported for crossbred and tropical breeds (Pollott et al., 1994; Hall et al., 1995; Pitono and James, 1995; Davis et al., 1998). Most studies of genetic parameters in sheep have used purebred animals and have focused on body weights. Studies that have used crossbred and composite breeds include those of Waldron et al. (1992), Fossceco and Notter (1995), Jones et al. (1999), El Fadili and Leroy (2001) and Rosati et al. (2002). 
Correct selection is one of the most important strategies to maximize production in animal breeding. However, the lack of estimates for the genetic parameters necessary to predict genetic gains is commonly cited as an obstacle in the design and implementation of conservation-based selective breeding programs in the tropics. As a result, there are few reports on successful selective breeding programs in this region (Gizaw et al., 2007). Estimates of genetic parameters are necessary to determine the selection method to be used, to estimate the maximum genetic gain that can be achieved and to obtain correct estimates of breeding values. However, there have been few estimates of the genetic parameters for growth, reproductive and maternal traits in sheep in Brazil. Sousa et al. $(1999,2006)$ and Sarmento et al. (2006) described results obtained with the purebred Santa Inês, but there have been no studies with crossbred sheep.

According to Robinson et al (1981), the use of models involving different genetic groups can account for all genetic influences, including non-linear and epistatic effects. However, additive genetic variance and heritability have been shown to be overestimated in an additive model with progeny groups in multibreed population. Van Der Werf and De Boer (1989) pointed out that crossbreeding parameters may be hard to estimate, particularly from field data, and that well-designed experiments are prerequisite for meaningful results. In their simulation study, the overestimation of additive variance and heritability was relatively small for levels of heterosis and recombination $\leq 5 \%$. Rodriguez-Almeida et al. (1997) reported that the separation of estimates of the mean genetic effects on traits in multibreed populations of beef cattle into those attributable to the genetic make-up of the calf and those attributable to the genetic makeup of the dam required data from a variety of crosses. The authors considered that, in beef cattle, there are a limited number of breeds or crosses in any herd. Consequently, the estimation of direct and maternal breed genetic effects from field data sets may not be possible. The development of a system for evaluating crossbred records will require the incorporation of information from adequately designed crossbreeding experiments.

The lack of systematic record keeping by Brazilian sheep breeders means that there have been few studies of the genetic parameters related to reproductive and maternal traits in the Brazilian flock. This lack of information greatly hinders adequate development of the meat sheep industry in which the reproductive and maternal efficiencies of ewes must be constantly evaluated in order to ensure profitable production. The aim of this study was therefore to estimate the additive genetic parameters for growth, reproductive and maternal traits in meat sheep of a multibreed population raised in Brazil.

\section{Materials and Methods}

The data bank analyzed contained 12 years (19962007) of information from a flock maintained by Gaasa
Agropecuária Ltda. and supported by the Programa de Melhoramento Genético de Caprinos e Ovinos de Corte (GENECOC) of Embrapa Caprinos e Ovinos. This herd is located at Inhumas in the state of Goiás (altitude $770 \mathrm{~m}$, $16^{\circ} 21^{\prime} 28^{\prime \prime} \mathrm{S}, 49^{\circ} 29^{\prime} 45^{\prime \prime} \mathrm{W}$ ) with a tropical semi-humid climate.

The sheep underwent standard sanitary care and were vaccinated with Poli-Star ${ }^{\circledR}$ (against botulism, enterotoxemia, gangrene and symptomatic carbuncle) at 50 and 80 days of age; all of the animals were vaccinated annually in March. Treatment for eimeriosis was done twice a year (March and October). Fecal egg counts and the Famacha method were used to control gastrointestinal nematodes. Footbaths ( $50 \mathrm{~g}$ of copper sulfate in $60 \mathrm{~mL}$ of $40 \%$ formaldehyde) were used during the rainy season.

The breeding season was year round with ewes grouped by lots. The lambs were weaned at 60 days, confined, and fed with maize silage and corn and soy bran meal containing $21 \%$ crude protein $(\mathrm{CP})$; they were slaughtered at 120-150 days. After weaning the lambs, the ewes underwent a 30-day breeding season in the presence of vasectomized rams. Ewes and rams were fed with Tifton 85 pasture, silage and meal containing $15 \% \mathrm{CP}$.

To understand the flock formation, initially purebred Santa Inês, Poll Dorset, Hampshire Down, Suffolk, Île de France, Brazilian Somali and Texel rams were acquired with Santa Inês, Poll Dorset, Morada Nova, Brazilian Somali, Santa Inês x Morada Nova and Santa Inês x Brazilian Somali dams. Later, purebred Dorper, Primera and East Friesian rams were acquired. The matings were controlled but not designed. All rams of all breeds had the same opportunity to mate ewes of all genetic groups (purebred and crossbred). As a result, within a few years the flock was a mixture of crossbred dams with a varied contribution from the different breeds. Only the rams and some Santa Inês, Poll Dorset and Brazilian Somali dams were purebred.

Data used in this study were obtained several years after formation of the flock, and already contained of the all breeds indicated above. However, many genetic groups were excluded from analysis because of insufficient information. The rams used included purebred Santa Inês (36), Poll Dorset (16), Hampshire Down (5), East Friesian (4), Dorper (4), Suffolk (3), Île de France (2), Brazilian Somali (2), Texel (1) and Primera (1). The dams used included purebred Santa Inês, Poll Dorset, Brazilian Somali and crossbreeds involving all of the breeds indicated above. Table 1 shows the genetic groups analyzed.

The growth traits analyzed included birth weight (BW), weaning weight (WW), slaughter weight (SW), yearling weight (YW), weight gain from birth to weaning (GBW), weight gain from weaning to slaughter (GWS) and weight gain from weaning to yearling (GWY). The WW of lambs $>30$ days old but weighing $<5 \mathrm{~kg}$ were excluded. Likewise, the SW of animals with a slaughter age $>365$ days were also excluded. All weights from animals 330- 
Table 1 - Genetic groups analyzed in this work and the number of observations $(\mathrm{N})$.

\begin{tabular}{|c|c|}
\hline Genetic groups & $\mathrm{N}$ \\
\hline 1/2 Dorper $+1 / 2$ Santa Inês & 275 \\
\hline 1/2 Dorper $+1 / 2$ Brazilian Somali & 202 \\
\hline 1/2 Dorper $+1 / 4$ Île de France + 1/4 Santa Inês & 36 \\
\hline 1/2 Dorper $+1 / 4$ Poll Dorset $+1 / 4$ Santa Inês & 198 \\
\hline 1/2 Dorper $+1 / 4$ Suffolk + 1/4 Santa Inês & 42 \\
\hline 1/2 Dorper $+1 / 4$ Texel $+1 / 4$ Santa Inês & 103 \\
\hline 1/2 East Friesian $+1 / 2$ Santa Inês & 61 \\
\hline 1/2 Hampshire Down $+1 / 2$ Santa Inês & 128 \\
\hline 1/2 Île de France $+1 / 2$ Santa Inês & 125 \\
\hline 1/2 Île de France + 1/4 Poll Dorset + 1/4 Santa Inês & 24 \\
\hline 1/2 Poll Dorset $+1 / 2$ Santa Inês & 681 \\
\hline 1/2 Poll Dorset $+1 / 2$ Brazilian Somali & 43 \\
\hline 1/2 Poll Dorset $+1 / 4$ Dorper $+1 / 4$ Santa Inês & 25 \\
\hline $1 / 2$ Primera $+1 / 2$ Santa Inês & 44 \\
\hline 1/2 Primera + 1/4 Poll Dorset + 1/4 Santa Inês & 26 \\
\hline 1/2 Santa Inês $+1 / 2$ Brazilian Somali & 145 \\
\hline $1 / 2$ Suffolk $+1 / 2$ Santa Inês & 65 \\
\hline 1/2 Texel + 1/2 Santa Inês & 102 \\
\hline 3/4 Dorper + 1/4 Santa Inês & 223 \\
\hline 3/4 Dorper + 1/4 Brazilian Somali & 115 \\
\hline 3/4 Dorper $+1 / 8$ Île de France + 1/8 Santa Inês & 35 \\
\hline 3/4 Dorper + 1/8 Poll Dorset + 1/8 Santa Inês & 80 \\
\hline 3/4 Poll Dorset + 1/4 Santa Inês & 315 \\
\hline 3/4 Santa Inês + 1/4 Hampshire Down & 23 \\
\hline 3/4 Santa Inês + 1/4 Île de France & 28 \\
\hline 3/4 Santa Inês + 1/4 Poll Dorset & 131 \\
\hline 3/4 Santa Inês + 1/4 Brazilian Somali & 62 \\
\hline 3/4 Santa Inês + 1/4 Suffolk & 36 \\
\hline 3/4 Santa Inês + 1/4 Texel & 22 \\
\hline 7/8 Santa Inês + 1/8 Poll Dorset & 42 \\
\hline Poll Dorset & 170 \\
\hline Santa Inês & 8212 \\
\hline Brazilian Somali & 124 \\
\hline
\end{tabular}

395 days old were considered as YW. The YW of lambs $>20 \mathrm{~kg}$ were excluded.

The reproductive and maternal traits analyzed included age at first lambing (AFL), lambing interval (LI), gestation length (GL), lambing date (LD; number of days between the start of breeding season and lambing), litter weight at birth (LWB) and litter weight at weaning (LWW). Data for animals with an AFL > 800 days and an LI > 550 days were excluded. Lambing orders from 1 to 8 were analyzed.

The MIXED procedure of SAS (SAS Institute Inc., 1996) was used to define fixed effects in the analysis. For each trait, many linear models were evaluated, with the use of contemporary groups or effects being analyzed individually. The logarithm of the Restricted Maximum Likelihood, Aikaikes's Information Criteria and Schwarz's Bayesian Information Criteria were the criteria for choice of the best fit.
For growth traits, contemporary groups (CG) were formed by grouping animals born in the same year-season and with the same sex, genetic group and birth type (single, twin, triplet). Only CGs with a minimum of five animals were considered. The birth seasons were: season 1 - January, February and March, season 2 - April, May and June, season 3 - July, August and September, and season 4 - October, November and December.

For reproductive and maternal traits, two CGs were created: the first for AFL and the second for other traits. For AFL, the CG consisted of animals born in the same yearseason, of the same genetic group, birth type (single, twin, triplet) and interaction of birth type with lamb sex (1 - one male lamb, 2 - one female lamb, 3 - two male lambs, 4 - two females lambs, 5 - one male lamb and one female lamb or 6 - more than two lambs, independent of sex). For the other traits, the CGs consisted of animals of the same genetic group, with lambing in the same year-season, the same birth type ( 1 to 6 , as defined above) and the same lambing order. Only CGs with a minimum of five animals were considered.

After preliminary analysis and based on criteria used to determine the best fit, the following fixed models were used, depending on the trait:

BW - contemporary group and age class of the dam at lambing (1 to 8 years);

WW and GBW - contemporary group, age class of the dam at lambing and lamb age (days) at weaning as linear and quadratic covariates;

SW and GWS - contemporary group and animal age (days) at slaughter as the covariate (linear and quadratic);

YW and GWY - contemporary group and animal age (days) on the date the animal was weighed as the covariate (linear and quadratic);

AFL, LI, GL, LD, TBW and TWW - contemporary groups.

The (co)variances and genetic parameters were estimated by the Average Information Restricted Maximum Likelihood method (AI-REML) using the software WOMBAT (Meyer, 2006), with single or multiple trait animal models. WOMBAT assesses whether an analysis has converged, based on the following criteria: 1) a change in $\log \mathrm{L}$ of $<5 \times 10^{-4}, 2$ ) a change in parameters of $<10^{-8}$ and 3 ) a gradient vector norm $<10^{-3}$.

The relationship matrix included 16,808 animals. Of these, 75 were rams and 4,272 were ewes, 13,124 animals had a complete pedigree (sire and dam known) and 1,251 were from the basal flock; 224 animals had an unknown sire. There was an average of 156 lambs per ram and 901 lambs per ram breed.

The general model for growth traits was:

$$
Y=X \beta+Z_{1} a+Z_{2} m+Z_{3} p e+e
$$

where $Y$ is a $(\mathrm{Nx} 1)$ vector of observations, $\beta$ is the vector of fixed effects related to the incidence matrix $X$, a is the vec- 
tor of direct genetic effects related to the incidence matrix $Z_{1}, m$ is the vector of maternal genetic effects related to the incidence matrix $Z_{2}$, pe is the vector of permanent environmental maternal effects related to the incidence matrix $Z_{3}$, and $e$ is the vector of random residuals.

The fixed effects have already been described previously. The general model presented above was used for BW, WW and GBW. The components $Z_{2} m$ and $Z_{3}$ pe were not included in the analysis of SW, YW, GWS and GWY. BW, WW and SW were analyzed in a multiple trait model. YW was analyzed in a multiple trait model with BW and WW. GBW was analyzed with GWS in one analysis and with GWY in another analysis.

Using the same general model described previously for all reproductive and maternal traits, the $Z_{2} m$ component was not considered and the $Z_{3}$ pe component refers to permanent environmental effects on the animal and was included only for traits measured many times on the same animal (LI, GL, LD, TBW and TWW). These two components were not included for AFL. AFL, LI and GL were analyzed in a multiple trait model, as were TBW and TWW. LD was analyzed in a single trait model.

The crossbreeding in this population was completely random, i.e., there was no specific design in the breeding pattern used. As an initial simplification in the data analysis, the average effect (additive and non-additive) of the genetic groups was considered to be fixed.

\section{Results}

The number of observations and the means for the traits analyzed are shown in Table 2. The means for WW
Table 2 - Number of observations $(\mathrm{N})$, means and standard deviations (SD) for the traits analyzed in this work.

\begin{tabular}{lrr}
\hline Trait & \multicolumn{1}{c}{$\mathrm{N}$} & Mean $\pm \mathrm{SD}$ \\
\hline Birth weight (kg) & 11,943 & $3.84 \pm 0.86$ \\
Weaning weight (kg) & 10,043 & $15.52 \pm 3.99$ \\
Slaughter weight (kg) & 1,542 & $31.96 \pm 6.22$ \\
Yearling weight (kg) & 1,208 & $41.15 \pm 7.64$ \\
Weight gain from birth to & 10,043 & $0.213 \pm 0.063$ \\
weaning (kg/day) & & \\
Weight gain from weaning to & 1,490 & $0.234 \pm 0.085$ \\
slaughter (kg/day) & & \\
Weight gain from weaning to & 1,177 & $0.087 \pm 0.024$ \\
yearling (kg/day) & & \\
Age at first lambing (days) & 2,154 & $532.71 \pm 90.20$ \\
Lambing interval (days) & 4,600 & $267.23 \pm 56.87$ \\
Gestation length (days) & 6,930 & $150.93 \pm 3.20$ \\
Lambing date (days) & 1,437 & $164.72 \pm 9.04$ \\
Litter weight at birth (kg) & 7,022 & $4.95 \pm 1.55$ \\
Litter weight at weaning (kg) & 6,217 & $18.34 \pm 6.73$ \\
\hline
\end{tabular}

and SW were $15.52 \mathrm{~kg}$ and $31.96 \mathrm{~kg}$, respectively. In this flock, the average ages at weaning and slaughter were $55.68 \pm 12.41$ days and $128.74 \pm 44.97$ days, respectively, indicating a high potential for precocity under the feeding conditions used here.

The estimates of (co)variance, Log L value, heritabilities and genetic correlations for a multiple trait analysis for BW, WW and SW are summarized in Table 3. Negative genetic covariances were observed between direct and maternal effects for BW and WW. The direct heritabilities for

Table 3 - Estimates of (co)variances $\left(\mathrm{kg}^{2}\right)$, heritabilities and genetic correlations for birth weight (BW), weaning weight (WW) and slaughter weight $(\mathrm{SW})$ in the multiple trait model.

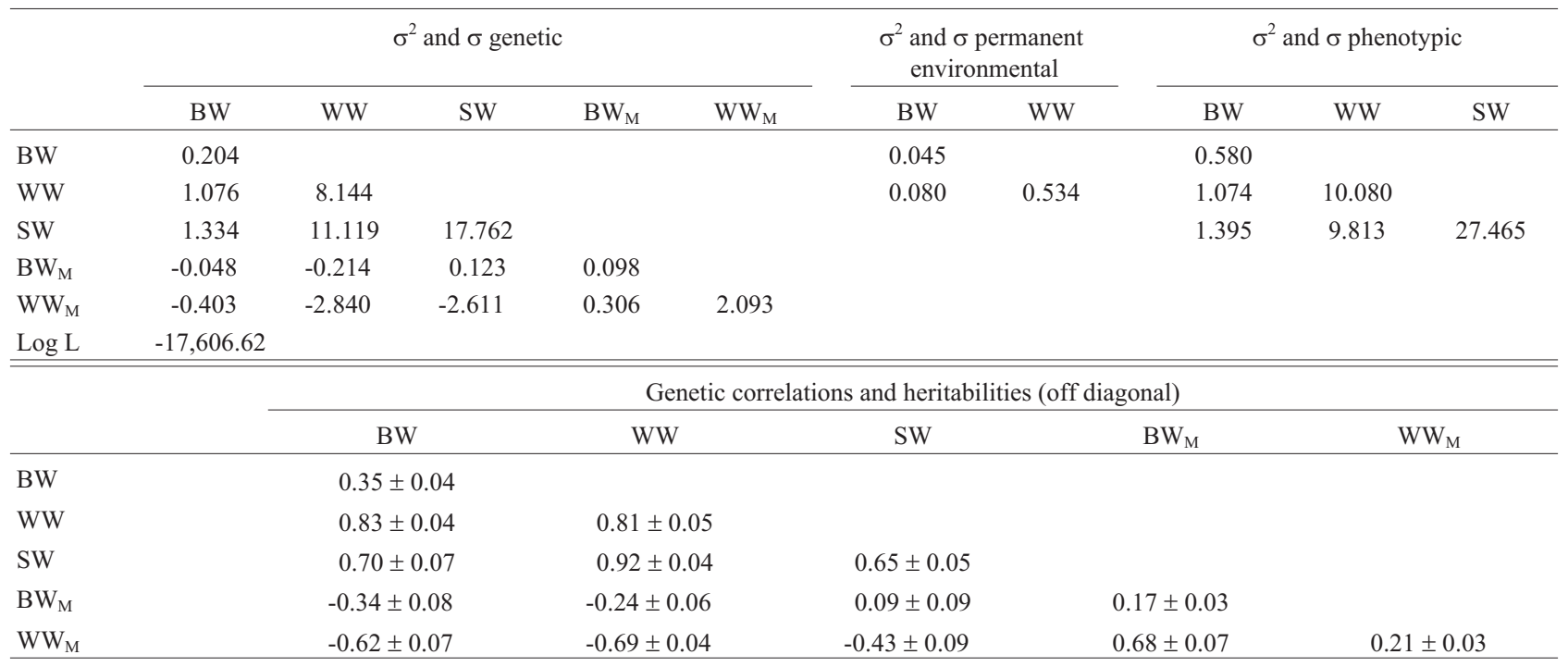

$\sigma^{2}=$ variances and $\sigma=$ covariances. $\mathrm{BW}=$ genetic direct effect for birth weight, $\mathrm{BW}_{\mathrm{M}}=$ genetic maternal effect for birth weight, Log $\mathrm{L}=\operatorname{logarithm}$ of the

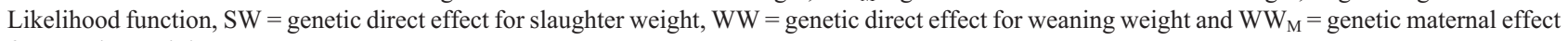
for weaning weight. 
BW, WW and SW were moderate to high (0.35-0.81). The maternal heritability for WW (0.21) was higher than for BW (0.17), indicating moderate genetic maternal variability in the flock that could be used to select for maternal ability. The genetic correlations among these traits were high (0.70-0.92).

Table 4 shows the (co)variances, $\log \mathrm{L}$ value, heritabilities and genetic correlations for multiple trait analysis with BW, WW and YW. As with BW, WW and SW, there were negative genetic covariances between genetic and maternal effects for BW and WW. The direct heritabilities ranged from moderate to high, indicating a potential for the selection of these traits in this flock. Heritability for BW was higher than in the previous analysis $(0.42 v s .0 .35)$ but was lower for WW $(0.60 v s .0 .81)$. The genetic correlations were high, with a maximum of 0.89 between BW and WW, as also observed in the analysis with BW, WW and SW. Comparison of Tables 3 and 4 shows that there were similarities between the two multiple trait analyses.

The (co)variances, Log L value, heritabilities and genetic correlations for multiple trait analysis with GBW and GWS are summarized in Table 5. The results for the analy-

Table 4 - Estimates of (co)variances $\left(\mathrm{kg}^{2}\right)$, heritabilities and genetic correlations for birth weight (BW), weaning weight (WW) and yearling weight (YW) in the multiple trait model.

\begin{tabular}{|c|c|c|c|c|c|c|c|c|c|c|}
\hline & \multicolumn{5}{|c|}{$\sigma^{2}$ and $\sigma$ genetic } & \multicolumn{2}{|c|}{$\begin{array}{c}\sigma^{2} \text { and } \sigma \text { permanent } \\
\text { environmental }\end{array}$} & \multicolumn{3}{|c|}{$\sigma^{2}$ and $\sigma$ phenotypic } \\
\hline & BW & WW & YW & $\mathrm{BW}_{\mathrm{M}}$ & $\mathrm{WW}_{\mathrm{M}}$ & BW & WW & BW & WW & YW \\
\hline BW & 0.258 & & & & & 0.048 & & 0.606 & & \\
\hline WW & 1.071 & 5.622 & & & & 0.096 & 0.600 & 1.043 & 9.426 & \\
\hline YW & 1.065 & 6.778 & 12.691 & & & & & 1.082 & 6.509 & 25.944 \\
\hline $\mathrm{BW}_{\mathrm{M}}$ & -0.079 & -0.258 & 0.035 & 0.109 & & & & & & \\
\hline $\mathrm{WW}_{\mathrm{M}}$ & -0.421 & -1.782 & -0.538 & 0.311 & 1.581 & & & & & \\
\hline $\log \mathrm{L}$ & $-17,072.48$ & & & & & & & & & \\
\hline
\end{tabular}

\begin{tabular}{|c|c|c|c|c|c|}
\hline & \multicolumn{5}{|c|}{ Genetic correlations and heritabilities (off diagonal) } \\
\hline & BW & WW & YW & $\mathrm{BW}_{\mathrm{M}}$ & $\mathrm{WW}_{\mathrm{M}}$ \\
\hline BW & $0.42 \pm 0.04$ & & & & \\
\hline WW & $0.89 \pm 0.03$ & $0.60 \pm 0.05$ & & & \\
\hline YW & $0.59 \pm 0.08$ & $0.80 \pm 0.06$ & $0.49 \pm 0.06$ & & \\
\hline $\mathrm{BW}_{\mathrm{M}}$ & $-0.47 \pm 0.06$ & $-0.33 \pm 0.06$ & $0.03 \pm 0.09$ & $0.18 \pm 0.03$ & \\
\hline $\mathrm{WW}_{\mathrm{M}}$ & $-0.66 \pm 0.07$ & $-0.60 \pm 0.05$ & $-0.12 \pm 0.11$ & $0.75 \pm 0.07$ & $0.17 \pm 0.03$ \\
\hline
\end{tabular}

$\sigma^{2}=$ variances and $\sigma=$ covariances. $\mathrm{BW}=$ genetic direct effect for birth weight, $\mathrm{BW}_{\mathrm{M}}=$ genetic maternal effect for birth weight, $\log \mathrm{L}=\operatorname{logarithm}$ of the Likelihood function, $\mathrm{WW}=$ genetic direct effect for weaning weight, $\mathrm{WW}_{\mathrm{M}}=$ genetic maternal effect for weaning weight and $\mathrm{YW}=$ genetic direct effect for yearling weight.

Table 5 - Estimates of (co)variances $\left(\mathrm{kg} / \mathrm{day}^{2}\right)$, heritabilities and genetic correlations for weight gain from birth to weaning (GBW) and weight gain from weaning to slaughter (GWS) in the multiple trait model.

\begin{tabular}{|c|c|c|c|c|c|c|}
\hline & \multicolumn{2}{|c|}{$\sigma^{2}$ and $\sigma$ genetic } & \multicolumn{2}{|c|}{$\sigma^{2}$ and $\sigma$ permanent environmental } & \multicolumn{2}{|c|}{$\sigma^{2}$ and $\sigma$ phenotypic } \\
\hline & GBW & GWS & $\mathrm{GBW}_{\mathrm{M}}$ & GBW & GBW & GWS \\
\hline GBW & 0.000460 & & & 0.000146 & 0.002350 & \\
\hline GWS & -0.000259 & 0.000597 & & & -0.000290 & 0.003940 \\
\hline $\mathrm{GBW}_{\mathrm{M}}$ & -0.000010 & -0.000065 & 0.000152 & & & \\
\hline $\log \mathrm{L}$ & $26,704.43$ & & & & & \\
\hline
\end{tabular}

\begin{tabular}{lccc}
\hline \hline & & Genetic correlations and heritabilities (off diagonal) & GBW $_{\mathrm{M}}$ \\
\cline { 2 - 4 } & GBW & GWS & \\
GBW & $0.20 \pm 0.05$ & $0.15 \pm 0.06$ & $0.06 \pm 0.03$ \\
GWS & $-0.49 \pm 0.18$ & $-0.22 \pm 0.33$ & \\
\hline
\end{tabular}

$\sigma^{2}=$ variances and $\sigma=$ covariances. $\mathrm{GBW}=$ genetic direct effect for weight gain from birth to weaning, $\mathrm{GBW}_{\mathrm{M}}=$ genetic maternal effect for weight gain from birth to weaning, GWS = genetic direct effect for weight gain from weaning to slaughter and Log L $=\operatorname{logarithm}$ of the Likelihood function. 
sis using GBW and GWY are shown in Table 6. Direct heritabilities were 0.15 and 0.39 for GWS and GWY, respectively. Direct and maternal heritabilities for GBW ranged from 0.20 to 0.36 and from 0.06 to 0.11 , respectively, being lowest in the analysis with GBW and GWS. GBW was negatively correlated with posterior weight gains ( -0.49 with GWS and -0.56 with GWY).

Table 7 shows the estimates of (co)variances, $\log \mathrm{L}$ value, heritabilities and genetic correlations for multiple trait analysis with AFL, LI and GL. The heritabilities were low, ranging from 0.04 to 0.10 . The genetic correlation between AFL and GL was negative (-0.33), but was positive between AFL and LI and between LI and GL (0.19 each). However, the errors associated with these correlations were very high.
The (co)variances, $\log \mathrm{L}$ value, heritabilities and genetic correlation for the maternal traits LWB and LWW are shown in Table 8. The was a high, positive genetic correlation between these traits $(0.86)$ while the heritabilities were low ( 0.15 for LWB and 0.11 for LWW).

Table 9 shows the estimated parameters for LD. The heritability for this trait was low (0.05), indicating a strong influence of environmental and non-additive genetic effects on the traits examined. This estimate was similar to that for the lambing interval.

\section{Discussion}

Direct additive variances and heritabilities were higher than maternal genetic variances and heritabilities for all growth traits. In general, direct heritabilities tend to be

Table 6 - Estimates of (co)variances $\left(\mathrm{kg} / \mathrm{day}^{2}\right)$, heritabilities and genetic correlations for weight gain from birth to weaning (GBW) and weight gain from weaning to yearling $(\mathrm{GWY})$ in the multiple trait model.

\begin{tabular}{|c|c|c|c|c|c|c|}
\hline & \multicolumn{2}{|c|}{$\sigma^{2}$ and $\sigma$ genetic } & \multicolumn{2}{|c|}{$\sigma^{2}$ and $\sigma$ permanent environmental } & \multicolumn{2}{|c|}{$\sigma^{2}$ and $\sigma$ phenotypic } \\
\hline & GBW & GWY & $\mathrm{GBW}_{\mathrm{M}}$ & GBW & GBW & GWY \\
\hline GBW & 0.000890 & & & 0.000152 & 0.002447 & \\
\hline GWY & -0.000162 & 0.000093 & & & -0.000107 & 0.000235 \\
\hline $\mathrm{GBW}_{\mathrm{M}}$ & -0.000243 & 0.000110 & 0.000269 & & & \\
\hline \multirow[t]{3}{*}{$\log \mathrm{L}$} & $27,511.90$ & & & & & \\
\hline & & \multicolumn{5}{|c|}{ Genetic correlations and heritabilities (off diagonal) } \\
\hline & & GBW & & GWY & \multicolumn{2}{|c|}{$\mathrm{GBW}_{\mathrm{M}}$} \\
\hline GBW & & $0.36 \pm 0.08$ & & & & \\
\hline GWY & & $-0.56 \pm 0.10$ & & $0.39 \pm 0.09$ & & \\
\hline $\mathrm{GBW}_{\mathrm{M}}$ & & $-0.50 \pm 0.12$ & & $0.70 \pm 0.13$ & \multicolumn{2}{|c|}{$0.11 \pm 0.03$} \\
\hline
\end{tabular}

$\sigma^{2}=$ variances and $\sigma=$ covariances. $\mathrm{GBW}=$ genetic direct effect for weight gain from birth to weaning, $\mathrm{GBW}_{\mathrm{M}}=$ genetic maternal effect for weight gain from birth to weaning, GWY = genetic direct effect for weight gain from weaning to yearling and $\log \mathrm{L}=\operatorname{logarithm}$ of the Likelihood function.

Table 7 - Estimates of (co)variances $\left(\mathrm{day}^{2}\right)$, heritabilities and genetic correlations for age at first lambing (AFL), lambing interval (LI) and gestation length (GL) in the multiple trait model.

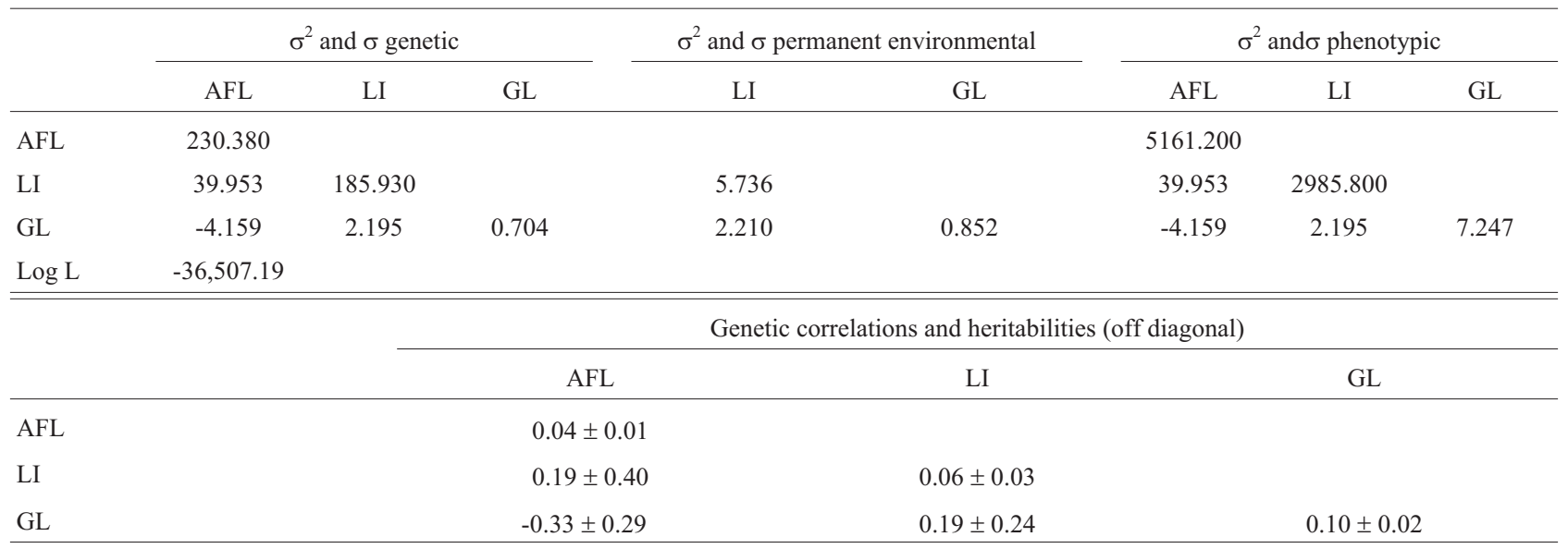

$\sigma^{2}=$ variances and $\sigma=$ covariances. $\log L=\operatorname{logarithm}$ of the Likelihood function. 
Table 8 - Estimates of (co)variances $\left(\mathrm{kg}^{2}\right)$, heritabilities $\left(\mathrm{h}^{2}\right)$ and genetic correlation for litter weight at birth (LWB) and litter weight at weaning (LWW) in the multiple trait model.

\begin{tabular}{|c|c|c|c|c|c|c|c|c|}
\hline & \multicolumn{2}{|c|}{$\sigma^{2}$ and $\sigma$ genetic } & \multicolumn{2}{|c|}{$\sigma^{2}$ and $\sigma$ permanent environmental } & \multicolumn{2}{|c|}{$\sigma^{2}$ and $\sigma$ phenotypic } & \multirow[b]{2}{*}{$\mathrm{h}^{2}$} & \multirow[b]{2}{*}{$r_{g}$} \\
\hline & LWB & LWW & LWB & LWW & LWB & LWW & & \\
\hline LWB & 0.144 & & 0.053 & & 0.947 & & $0.15 \pm 0.02$ & $0.86 \pm 0.08$ \\
\hline LWW & 0.604 & 3.431 & 0.315 & 1.857 & 0.920 & 31.239 & $0.11 \pm 0.02$ & \\
\hline $\log L$ & $-16,105.35$ & & & & & & & \\
\hline
\end{tabular}

$\sigma^{2}=$ variances and $\sigma=$ covariances. $h^{2}=$ heritability, $\mathrm{r}_{\mathrm{g}}=$ genetic correlation and $\log \mathrm{L}=$ logarithm of the Likelihood function.

Table 9 - Estimates of variances $\left(\sigma^{2} ;\right.$ day $\left.{ }^{2}\right)$, heritability $\left(h^{2}\right)$ and logarithm of the Likelihood function (-2Log L) for lambing date (LD) in the multiple trait model.

\begin{tabular}{lc}
\hline Parameters & LD \\
\hline$\sigma^{2}$ genetic & 3.3072 \\
$\sigma^{2}$ permanent environmental & 0.2271 \\
$\sigma^{2}$ phenotypic & 68.7890 \\
$\mathrm{~h}^{2}$ & $0.05 \pm 0.05$ \\
Log L & $-3,263.23$ \\
\hline
\end{tabular}

higher than maternal heritabilities for early growth traits (Hassen et al., 2003). Sarmento et al. (2006) observed heritabilities of 0.20 and 0.001 for birth weight and weaning weight, respectively, at 112 days of age in purebred Santa Inês sheep. Their estimate for BW was similar to that found here. This breed has a larger contribution in the population studied here (Table 1), which may explain this similarity. Tosh and Kemp (1994) estimated direct heritabilities of 0.39 and 0.22 for BW and WW in Hampshire Down purebred sheep. Lower direct heritabilities for BW and $\mathrm{WW}$, respectively, have been reported by others, e.g., 0.12 and 0.21 for Poll Dorset sheep (Tosh and Kemp, 1994), 0.09 and 0.09 for composite sheep (Mousa et al., 1999), 0.13 and 0.04 for Santa Inês sheep (Sousa et al., 1999) and 0.24 and 0.19 for dual purpose (wool and meat) crossbred sheep (Hall et al., 1995). Genetic parameters depend on the historical formation, selective forces and environmental aspects of a population, which partly explains differences among the results of different studies. However, it is possible that the values reported here were overestimated by non-additive effects.

Safari et al. (2005) reviewed the genetic parameters for growth, carcass and reproductive traits compiled from 165 studies in sheep published from 1992 to 2003, with estimates generally derived from mixed model REML procedures, in addition to some Bayesian estimates. The weighted means for direct heritability associated with birth, weaning and post-weaning weights and daily gain were $0.15 \pm 0.02,0.18 \pm 0.04,0.21 \pm 0.01$ and $0.17 \pm 0.01$, respectively, for meat breeds. The estimates described here were greater than the weighted means reported by these authors, which suggests that bias in our analysis resulted in overestimation of the parameters. According to Van Der Werf and De Boer (1989), additive genetic variance and heritability are overestimated when data from crossbred animals are analyzed by additive model without non-additive effects.

The maternal heritabilities for BW and WW were different from those of Sousa et al. (1999) for a purebred Santa Inês flock ( 0.12 for BW and 0.10 for WW) and of Mousa et al. (1999) for a composite breed, but were similar to those of Maria et al. (1993) for Romanov sheep. Tosh and Kemp (1994) reported maternal heritabilities of $0.22,0.31$ and 0.13 for BW and $0.14,0.19$ and 0.06 for weight at 50 days of age in Hampshire Down, Poll Dorset and Romanov sheep, respectively. In dual purpose crossbred sheep, Hall et al. (1995) reported maternal heritabilities of 0.08 for BW and 0.05 for WW. As shown here, the maternal effect was strong for BW and WW, indicating the importance of maternal ability in crossbred females in this population. Differences in the maternal effects among breeds have been attributed to variations in milk production (Meyer et al., 1994; Tosh and Kemp, 1994).

The (co)variance and correlation estimates between animal and maternal genetic effects were generally negative for all traits. Sarmento et al. (2006) reported genetic correlations $\left(\mathrm{r}_{\mathrm{am}}\right)$ of -0.47 and -0.24 between the direct and maternal effects for BW and WW, respectively, in purebred Santa Inês. These values were similar to those observed here, possibly because this breed provided the largest contribution to the flock in our study. Sousa et al. (1999), who also studied Santa Inês sheep, reported correlations of - 0.15 and -0.10 between direct and maternal effects for birth weight and weaning weight, respectively, at 112 days of age. Hassen et al. (2003) likewise reported antagonism between direct and maternal effects: from -0.48 to -0.23 for BW and from -0.69 to -0.57 for WW. Tosh and Kemp (1994) observed $r_{a m}$ of -0.56 and -0.35 for BW in Hampshire Down and Poll Dorset sheep, respectively. Janssens et al. (2000) reported an $r_{a m}$ of 0.03 for Belgian Texel sheep and Maniatis and Pollott (2002) reported a value of -0.64 for Suffolk sheep. In contrast, there have been no estimates for this correlation in multibreed sheep populations. The value estimated here suggests that it may be difficult for breeders to select for both aspects. Selection for direct effects allows a reduction in maternal effects and vice-versa. 
There is a lack of information on the genetic parameters for YW in Brazilian flocks. Matika et al. (2003) observed a direct heritability of 0.26 for weight at 12 months. Miraei-Ashtiani et al. (2007) cited a heritability of $0.10 \pm 0.05$ for yearling weight of Sangsari sheep in Iran, and Mokhtari et al. (2008) estimated the heritability of YW to be 0.15 in Kermani sheep. These values were lower than observed here, suggesting that we overestimated this parameter, probably because of non-addictive effects.

The high correlations between BW and WW (0.83), BW and SW (0.70) and WW and SW (0.92) indicated the possibility of a correlated response with the selection for a given trait. The greater heritability of SW and the high correlation between WW and SW suggested that animals may be selected at an early age.

Genetic correlations ranging from -0.33 to 0.81 have been reported between BW and WW in different breeds and at different ages (Lewer et al., 1994; Vaez Torshizi et al., 1996; Analla et al., 1997; Yazdi et al., 1997; Mousa et al., 1999; Neser et al., 2001; Wuliji et al., 2001; Boujenane and Kansari, 2002; Duguma et al., 2002; Hanford et al., 2002; Simm et al., 2002). Correlations between BW and weight at 90 days of age (0.56) and post-weaning weight at 120 days of age (0.44) were reported by Nasholm and Danell (1996) in Swedish finewool sheep, and between BW and weight at 174 days of age (0.48) by Analla et al. (1997) in Merino sheep. High genetic correlations (0.83-0.98) between WW and post-weaning weights have also been reported (Nagy et al., 1999; Wuliji et al., 2001; Yazdi et al., 1997; Snyman et al., 1998). Miraei-Ashtiani et al. (2007) reported a genetic correlation of 0.43 between WW and YW, and Gizaw et al. (2007) estimated this correlation to be $0.69 \pm 0.01$. These estimates were lower than described here, probably because we overestimated these values as a result of nonadditive effects.

A knowledge of the magnitude and directions of the correlations among traits is important for establishing efficient selection strategies. As expected, the correlation between WW and YW was greater than between BW and YW. Nevertheless, in both cases, the correlations indicated that selection for one trait would positively affect the response to the other.

An understanding of the additive genetic variation for weight gain is extremely important for breeding programs. The direct $(0.20)$ and maternal (0.06) heritabilities for GBW (Table 5) were similar to those reported by Maria et al. (1993) for Romanov sheep. Matika et al. (2003) reported direct and maternal heritabilities and correlation between direct and maternal effects of $0.17,0.04$ and -0.08 , respectively, for the pre-weaning average daily weight gain in Sabi sheep. Hagger (1998) observed a correlation of -0.45 between the direct and maternal effects for this same trait. The direct heritability estimated here for GWY was similar to that reported by Mousa et al. (1999) for post- weaning average daily weight gain in a composite terminal sire breed.

The negative correlations between GBW and GWS/GWY may reflect the limited number of observations for these parameters, partly because of the way the data were distributed. The animals in this flock were slaughtered between 120 and 150 days of age (128 on average), with only the males and females selected for reproduction reaching one year of age. Consequently, birth-toweaning data were distributed into the weaning-toslaughter and weaning-to-yearling groups. In addition, some lambs did not reach weaning. These negative correlations may also reflect differences in the animals responses to pre- and post-weaning environmental conditions, such as occurs in genotype $v s$. environmental interactions. In the pre-weaning period, the animals were maintained in confined conditions, whereas after weaning they had access to pasture and food supplementation.

AFL and LI were strongly influenced by environmental effects, whereas GL showed little inter-individual variation. Hence, the low heritabilities estimated for these traits were expected. A heritability of 0.27 for LI was estimated by McManus and Miranda (1998), but there was a high standard error (0.29). The low estimates observed here for reproductive traits did not mean that there was no possibility for genetic improvement, but rather that the expected genetic gain was low if selection for these traits was also low.

According Rosati et al. (2002), a low heritability for reproductive traits probably reflects a proportionally greater influence of environmental effects, as well as a low genetic variability for fertility, litter size, lamb survival, lambing frequency and other reproductive traits (Turner and Young, 1969). Heritability for LWB was similar to that reported by McManus and Miranda (1998), but their estimate of heritability for LWW differed from that observed here. Rosati et al. (2002) reported heritabilities of 0.40 and 0.17 for total litter weight at birth and total litter weight at weaning for purebred, composite and crossbred sheep based on an additive model in which the ewe breed effect was fixed (as done here). These authors commented on the high values they obtained for these traits and pointed out that heritability estimates may be influenced by other factors not considered in the model; non-additive effects were not considered and their estimates were generally higher than observed here. The large positive genetic correlation between LWB and LWW suggests that productivity can also be selected based on LWW.

The similarity between the values for LD and LI suggests that these traits had essentially the same characteristics, possibly because of the reproductive management of the flock. The exposure of ewes to mating seasons meant that LI was probably not a good trait for selection because of possible bias. In this case, LD would probably be more efficient for selecting fertility because there would be no 
breeder-introduced bias, i.e., the ewes would be unable to express their full reproductive potential because the mating season was limited to a particular period. However, since in this flock the mating season was essentially continuous the year round, all of the ewes had an opportunity to mate at eight-month intervals.

In conclusion, the results of this study show that there is strong maternal influence in this herd and the presence of sufficient genetic variation to allow mass selection for growth traits. Additive effects were of little importance for reproductive traits, and other strategies are necessary to improve the performance of these animals. However, the estimates presented here should be interpreted cautiously because of possible bias introduced by the absence of nonadditive effects in the model used here. This model was chosen primarily because the lack of information on genetic parameters in Brazilian sheep precluded the choice of a more adequate one. Consequently, it is possible that the additive variance and heritability for some traits were overestimated. Nevertheless, the results described here provide a starting point for more detailed studies on the genetic parameters of multibreed sheep in Brazil.

\section{Acknowledgments}

Financial support was provided by Conselho Nacional de Desenvolvimento Científico e Tecnológico (CNPq) and Embrapa Caprinos e Ovinos. The authors thank the anonymous reviewers for many helpful suggestions.

\section{References}

Analla M, Munoz-Serrano A and Serradilla JM (1997) Analysis of genetic relationships between litter size and weight traits in Segurena sheep. Can J Anim Sci 77:17-21.

Barros NN, Vasconcelos VR and Lobo RNB (2004) Características de crescimento de cordeiros de cordeiros $\mathrm{F} 1$ para abate no semi-árido do Nordeste do Brasil. Pesq Agrop Bras 39:809-814 (Abstract in English).

Barros NN, Vasconcelos VR, Wander AE and Araújo MRA (2005) Eficiência bioeconômica de cordeiros F1 Dorper x Santa Inês para produção de carne. Pesq Agrop Bras 40:825-831 (Abstract in English).

Boujenane I and Kansari J (2002) Estimates of (co)variances due to direct and maternal effects for body weights in Timahdite sheep. Anim Sci 74:409-414.

Davis GH, Morris CA and Dodds KG (1998) Genetic studies of prolificacy in New Zealand sheep. Anim Sci 67:289-297.

Dickerson GE (1970) Efficiency of animal production - Molding the biological components. J Anim Sci 30:849-859.

Duguma G, Schoeman SJ, Cloete SWP and Jordaan GF (2002) Genetic parameter estimates of early growth traits in the Tygerhoek Merino flock. S Afric J Anim Sci 32:66-75.

El Fadili M and Leroy PL (2001) Estimation of additive and non-additive genetic parameters for reproduction, growth and survival traits in crosses between the Moroccan D'man and Timahdite sheep breeds. J Anim Breed Genet 118:341353.
Fossceco SL and Notter DR (1995) Heritabilities and genetic correlations of body weight, testis growth and ewe lamb reproductive traits in crossbred sheep. Anim Sci 60:185-195.

Gizaw S, Lemma S, Komen H and Van Arendonk JAM (2007) Estimates of genetic parameters and genetic trends for live weight and fleece traits in Menz sheep. Small Rum Res 70:145-153.

Hagger C (1998) Litter, permanent environmental, ram-flock, and genetic effects on early weight gain of lambs. J Anim Sci 76:452-457.

Hall DG, Fogarty NM and Gilmour AR (1995) Performance of crossbred progeny of Trangie Fertility Merino and Booroola Merino rams and Poll Dorset ewes. 1. Lamb birth weight, survival and growth. Aust J Exp Agric 35:1069-1074.

Hanford KJ, van Vleck LD and Snowder GD (2002) Estimates of genetic parameters and genetic change for reproduction, weight, and wool characteristics of Columbia sheep. J Anim Sci 80:3086-3098.

Hassen Y, Fuerst-Waltl B and Sölkner J (2003) Genetic parameter estimates for birth weight, weaning weight and average daily gain in pure and crossbred sheep in Ethiopia. J Anim Breed Genet 120:29-38.

Janssens S, Geysen D and Vandepitte W (2000) Genetic parameters for liveweight in Belgian Texel sheep. Proceedings of the 51st Annual Meeting of the European Association for Animal Production, Session 1.6.

Jones HE, Simm G, Dingwall WS and Lewis RM (1999) Genetic relationships between visual and objective measures of carcass composition in crossbred lambs. Anim Sci 69:553-561.

Kosgey IS, Van Arendonk JAM and Baker RL (2004) Economic values for traits of meat sheep in medium to high production potential areas of the tropics. Small Rumin Res 50:187-202.

Lewer RP, Woolaston RR and Howe RR (1994) Studies on Western Australian Merino sheep 2. Genetic and phenotypic parameter estimates for objectively measured traits on ram and ewe hoggets using different model types. Aust J Agric Res 45:829-840.

Maniatis N and Pollott GE (2002) Maternal effects on weight and ultrasonically measured traits of lambs in a small closed Suffolk flock. Small Rum Res 45:235-246.

Maria GA, Boldman KG and Van Vleck LD (1993) Estimates of variance due to direct and maternal effects for growth traits of Romanov sheep. J Anim Sci 71:845-849.

Matika O, van Wyk JB, Erasmus GJ and Baker RL (2003) Genetic parameter estimates in Sabi sheep. Small Rum Res 79:1728.

McManus C and Miranda RM (1998) Estimativas de parâmetros genéticos em ovinos Bergamácia. Braz J Anim Sci 27:916921 (Abstract in English).

Meyer K (2006) WOMBAT - A program for mixed model analyses by restricted maximum likelihood. User notes. Animal Genetics and Breeding Unit, Armidale, 58 pp.

Meyer K, Carrick MJ and Donnelly BJP (1994) Genetic parameters for milk production of Australian beef cows and weaning of their calves. J Anim Sci 72:1155-1165.

Miraei-Ashtiani SR, Seyedalian SAR and Shahrbabak MM (2007) Variance components and heritabilities for body weight traits in Sangsari sheep, using univariate and multivariate animal models. Small Rum Res 73:109-114. 
Mokhtari MS, Rashidi A and Mohammadi Y (2008) Estimation of genetic parameters for pos-weaning traits of Kermani sheep. Small Rum Res 80:22-27.

Mousa E, Van Vleck LD and Leymaster A (1999) Genetic parameters for growth traits for a composite terminal sire breed of sheep. J Anim Sci 77:1659-1665.

Nagy I, Solkner J, Komlosi I and Safar L (1999) Genetic parameters of production and fertility traits in Hungarian Merino sheep. J Anim Breed Genet 116:399-413.

Nasholm A and Danell O (1996) Genetic relationships of lamb weight, maternal ability, and mature ewe weight in Swedish finewool sheep. J Anim Sci 74:329-339.

Neser FWC, Erasmus GJ and van Wyk JB (2001) Genetic parameter estimates for pre-weaning weight traits in Dorper sheep. Small Rum Res 40:197-202.

Pitono A and James JW (1995) Estimates of genetic parameters for lamb weights and growth traits of tropical sheep. Proceedings of the Australian Association of Animal Breeding and Genetics 11:425-429.

Pollott GE, Guy DR and Croston D (1994) Genetic parameters of lamb carcass characteristics at 3 end-points: Fat level, age and weight. Anim Prod 58:65-75.

Robinson OW, McDaniel BT and Rincon EJ (1981) Estimation of direct and maternal additive and heterotic effects from crossbreeding experiments in animals. J Anim Sci 52:44-50.

Rodriguez-Almeida FA, Van Vleck LD and Gregory KE (1997) Estimation of direct and maternal breed effects for prediction of expected progeny differences for birth and weaning in three multibreed populations. J Anim Sci 75:1203-1212.

Rosati A, Mousa E, van Vleck LD and Young LD (2002) Genetic parameters of reproductive traits in sheep. Small Rum Res 43:65-74

Safari E, Fogarty NM and Gilmour AR (2005) A review of genetic parameter estimates for wool, growth, meat and reproduction traits in sheep. Livest Prod Sci 92:271-289.

Sarmento JLR, Torres RA, Sousa WH, Pereira CS, Lopes PS and Breda FC (2006) Estimação de parâmetros genéticos para características de crescimento de ovinos Santa Inês utilizando modelos uni e multicaracterística. Braz J Vet Anim Sci 58:581-589 (Abstract in English).

SAS Institute Inc. (1996) SAS/STAT. User's Guide v. 6.11. 4th edition, SAS Institute Inc., Cary, 842 pp.

Silva FLR (2002) Desempenho de ovinos deslanados e mestiços criados em pastagem nativa, na região semi-árida do nordeste do Brasil. Rev Cient Prod Anim 4:71-76 (Abstract in English).
Silva LR and Araújo AM (2000) Características de reprodução e de crescimento de ovinos mestiços Santa Inês no Ceará. Braz J Anim Sci 29:1712-1720 (Abstract in English).

Simm G, Lewis RM, Grundy B and Dingwall WS (2002) Responses to selection for lean growth in sheep. Anim Sci 74:39-50.

Snyman MA, Erasmus GJ, van Wyk JB and Olivier JJ (1998) Genetic and phenotypic correlations among production and reproduction traits in Afrino sheep. S Afr J Anim Sci 28:7481.

Sousa JER, de Oliveira SMP, Lima FAM, Silva FLR and Silva MA (2006) Efeitos genéticos e de ambiente para características de crescimento em ovinos Santa Inês no Estado do Ceará. Rev Ciênc Agron 37:364-368 (Abstract in English).

Sousa WH, Pereira CS, Bergmann AG and Silva FLR (1999) Estimativas de componentes de (co)variânica e herdabilidade direta e materna de pesos corporais em ovinos da raça Santa Inês. Braz J Anim Sci 28:1252-1262 (Abstract in English).

Tosh JJ and Kemp RA (1994) Estimation of variance components for lamb weights in three sheep populations. J Anim Sci 72:1184-1190.

Turner HN and Young SY (1969) Quantitative Genetics in Sheep Breeding. MacMillan, Melbourne, 332 pp.

Vaez Torshizi R, Nicholas FW and Raadsma HW (1996) REML estimates of variance and covariance components for production traits in Australian Merino sheep, using an animal model, 1: Body weight from birth to 22 months. Aust J Agric Res 47:1235-1249.

Van Der Werf JHJ and De Boer W (1989) Influence of nonadditive effects on estimation of genetic parameters in dairy cattle. J Dairy Sci 72:2606-2614.

Waldron DF, Clarke JN, Rae A, Kirton AH and Bennett GL (1992) Genetic and phenotypic parameter estimates for selection to improve lamb carcass traits. New Zealand J Agric Res 35:287-298.

Wuliji T, Dodds KG, Land JTJ, Andrews RN and Turner PR (2001) Selection for ultrafine Merino sheep in New Zealand: Heritability, phenotypic and genetic correlations of live weight, fleece weight and wool characteristics in yearlings. Anim Sci 72:241-250.

Yazdi MH, Nasholm A, Johansson K, Jorjani H and Liljedahl LE (1997) Population parameters for birth and ewe fleece weight at different parities in Baluchi sheep. J Anim Breed Genet 114:323-332.

Associate Editor: Pedro Franklin Barbosa

License information: This is an open-access article distributed under the terms of the Creative Commons Attribution License, which permits unrestricted use, distribution, and reproduction in any medium, provided the original work is properly cited. 